\title{
Anticancer effects of liriodenine on the cell growth and apoptosis of human breast cancer MCF-7 cells through the upregulation of p53 expression
}

\author{
ZHI-HUA LI ${ }^{1,2}$, JIN GAO $^{3}$, PING-HUA HU ${ }^{2}$ and JIAN-PING XIONG ${ }^{1}$ \\ ${ }^{1}$ Department of Oncology, The First Affiliated Hospital of Nanchang University, Nanchang, Jiangxi 330009; \\ ${ }^{2}$ Prevention and Cure Center of Breast Disease, Third Hospital of Nanchang, Nanchang, Jiangxi 330009; \\ ${ }^{3}$ Department of Breast Surgery, The First Affiliated Hospital of Guangzhou Medical University, \\ Guangzhou, Guangdong 510120, P.R. China
}

Received February 27, 2016; Accepted February 23, 2017

DOI: $10.3892 / \mathrm{ol} .2017 .6418$

\begin{abstract}
Liriodenine has wide pharmacological functions in phytochemistry, pharmacology and antitumor activities. The anticancer effects of liriodenine on the cell growth and apoptosis of human breast cancer MCF-7 cells, and the underlying mechanisms, are yet to be elucidated. Therefore, the present study investigated the anticancer effects of liriodenine on the cell growth and apoptosis of human breast cancer MCF-7 cells. We used MTT assay to measure cell growth, and flow cytometer and DAPI staining was used to analyze cell apoptosis. Then, Western blot analysis was executed to measure B-cell lymphoma-2 protein (Bcl-2), cyclin D1, vascular endothelial growth factor (VEGF), and p53 protein expression. The effect of liriodenine induced significant apoptosis and suppression of cell growth of the MCF-7 cells. Furthermore, the potential mechanism underlying its antitumor effect on MCF-7 cells may result from activation of caspase-3 activity, Bcl-2, cyclin D1 and VEGF, and promotion of p53 protein expression in MCF-7 cells. Therefore, the present results indicated that the anticancer effects of liriodenine suppress cell growth and induce the apoptosis of human breast cancer MCF-7 cells through inhibition of Bcl-2, cyclin D1 and VEGF expression, and upregulation of p53 expression. Therefore, liriodenine may be a potential therapy for the treatment of human breast cancer.
\end{abstract}

\section{Introduction}

Breast cancer is a malignant cancer with the highest morbidity rate worldwide, and its onset age is decreasing (1). Each year,

Correspondence to: Professor Zhi-Hua Li, Department of Oncology, The First Affiliated Hospital of Nanchang University, Nanchang, Jiangxi 330009, P.R. China

E-mail: lizhnc@163.com

Key words: liriodenine, breast cancer, vascular endothelial growth factor, cyclin D1, p53
1.2 million females are diagnosed with breast cancer all over the world, among which the majority succumb at $40-45$ years old (2). According to its degree of infiltration, breast cancer may be divided in to pre-invasive and invasive carcinoma (3). Clinically, breast cancer originates from the breast ductal epithelium (4). The probability of being affected by breast cancer for each woman may be as high as $10 \%$ (4). High incidence areas of breast cancer lie in Europe and America, while the morbidity rate in Asia, Africa and Latin America is relatively low (5). Newly detected cases globally reach 1.2 million every year, and over one-third of patients with breast cancer succumb to the disease (6).

An increasing number of studies have become focused on investigating the association between the abnormity of cancer suppressor genes, particularly tumor protein p53 (TP53), which acts independently, and the occurrence and progression of breast cancer (7). A previous study revealed that estrogen receptor (ER), apoptosis-stimulating protein of $\mathrm{p} 53$, Noxa protein, ras gene and human epidermal growth factor receptor-2 may affect the progression of breast cancer through the p53 pathway (8). Therefore, novel therapeutic methods for breast cancer may be identified by studying the p53 pathway.

TP53 is the vital cancer suppressor gene in tumors. Under the stimulus of DNA damage or other stress signals, TP53 is activated and launches waterfall biological responses, resulting in cell cycle arrest, DNA repair, and apoptosis to block the occurrence and progress of tumors (9). The variation of TP53 may lead to the loss of its tumor suppressor functions and cause poorly-differentiated abnormal cells to survive and/or proliferate (10). Tumors carrying variant P53 genes may exhibit increased invasiveness and be more resistant to radiotherapy and chemotherapy, with a poorer prognosis (11).

Liriodenine has been extracted from plants and found to be an alkaloid with extensive pharmacological activities (12). Liriodenine is widely spread at low levels among different natural plants of various genera and families (13). Liriodenine demonstrates wide pharmacological activities with regard to antitumor, anti-bacteria, anti-fungus and anti-senile dementia functions $(12,14,15)$. The planar construction of liriodenine provides significant antineoplastic activity (16). The aim of 
the present study was to investigate the anticancer effect of liriodenine on the cell growth and apoptosis of human breast cancer, in order to evaluate whether it may present a potential antitumor drug for the treatment of the disease.

\section{Materials and methods}

Cell lines and cell culture. The MCF-7 human breast cancer cell was obtained from the Shanghai Cell Bank of the Chinese Academy of Sciences (Shanghai, China). MCF-7 cells were cultured in Dulbecco's modified Eagle's medium containing $100 \mu \mathrm{g} / \mathrm{ml}$ penicillin, $100 \mu \mathrm{g} / \mathrm{ml}$ streptomycin and $10 \%$ fetal bovine serum (all from Gibco; Thermo Fisher Scientific, Inc., Waltham, MA, USA) at $37^{\circ} \mathrm{C}$ in a humidified $\mathrm{CO}_{2}$ atmosphere until use.

MTT assay. In total, $1-1.5 \times 10^{4} \mathrm{MCF}-7$ cells/well were seeded onto 96-well plates and treated with liriodenine $(0,0.1,1$ and $10 \mu \mathrm{M}$ ) for $0,24,48$ and $72 \mathrm{~h}$. MCF-7 cells were cultured with $50 \mu \mathrm{l}$ MTT (Roche Diagnostics, Basel, Switzerland) for $4 \mathrm{~h}$. Dimethyl sulfoxide $(150 \mu \mathrm{l})$ was the added to the cells for $30 \mathrm{~min}$ to dissolve the formazan. The absorbance was measured in each well with a plate reader (Synergy-HY, BioTek Instruments $\mathrm{GmbH}$, Friedrichshall, Germany) at $550 \mathrm{~nm}$.

Apoptosis assay and DAPI staining. In total, $1 \times 10^{6} \mathrm{MCF}-7$ cells/well were seeded onto 6 -well plates and treated with liriodenine $(0,0.1,1$ and $10 \mu \mathrm{M})$ for $48 \mathrm{~h}$. The cells were stained with $10 \mu \mathrm{l}$ Annexin $\mathrm{V}$ for $30 \mathrm{~min}$ in the dark (KGI Biotechnology Development Co., Ltd., Nanjing, China) and stained with $10 \mu \mathrm{l}$ propidium iodide (KGI Biotechnology Development Co., Ltd.) for $5 \mathrm{~min}$ in the dark. Apoptotic rate was analyzed using the Guava EasyCyte ${ }^{\mathrm{TM}}$ flow cytometer (Merck KGaA, Darmstadt, Germany).

MCF-7 cells/well $\left(1 \times 10^{6}\right)$ were then seeded onto 6-well plates and treated with liriodenine $(0,0.1,1$ and $10 \mu \mathrm{M})$ for $48 \mathrm{~h}$. DAPI stain $(50 \mu \mathrm{g} / \mathrm{ml}$; Beyotime Institute of Biotechnology, Haimen, China) was added to the cells for $20 \mathrm{~min}$, which were then washed with phosphate-buffered saline. Images were captured using a DP70 fluorescence microscope (magnification, x10; Olympus Corporation, Tokyo, Japan) and analyzed using Quantity One software (version 3.0; Bio-Rad Laboratories, Inc., Hercules, CA, USA).

Caspase-3 activity. In total, 1-1.5x10 $\mathrm{MCF}-7$ cells/well were seeded onto 96 -well plates and treated with liriodenine $(0$, $0.1,1$ and $10 \mu \mathrm{M}$ ) for $48 \mathrm{~h}$. Caspase-3 activity was measured using Caspase-3 Activity assay kit (Beyotime, Jiangsu, China). Ac-DEVD-pNA (Beyotime) was added to each well and incubated for $30 \mathrm{~min}$ at $37^{\circ} \mathrm{C}$. The absorbance was measured in each well with a plate reader (Synergy-HY; BioTek Instruments $\mathrm{GmbH}$ ) at $405 \mathrm{~nm}$.

Western blot analysis. In total, $1 \times 10^{6} \mathrm{MCF}-7$ cells/well were seeded onto 6-well plates and treated with liriodenine $(0,0.1,1$ and $10 \mu \mathrm{M}$ ) for $48 \mathrm{~h}$. According to the manufacturer's protocol, the cells were lysed using radioimmunoprecipitation assay buffer (Beyotime Institute of Biotechnology). The protein concentrations were determined using a bicinchoninic acid kit (Beyotime Institute of Biotechnology). Total protein $(50 \mu \mathrm{g})$

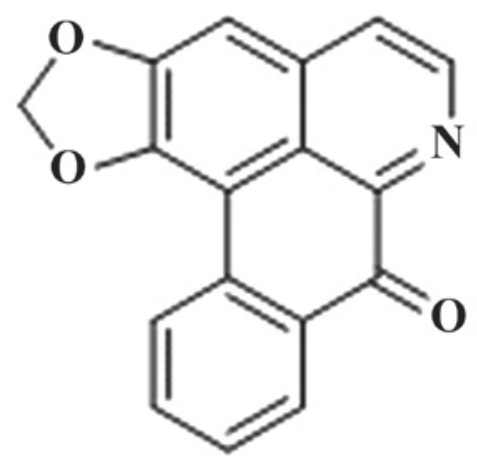

Figure 1. Chemical structure of liriodenine.

was isolated with $10 \%$ SDS-PAGE and transferred to a nitrocellulose membrane. The nitrocellulose membrane was blocked with 5\% skimmed milk powder in Tris-buffered saline with Tween-20 (TBST) for $1 \mathrm{~h}$ at room temperature, and incubated with antibodies against B-cell lymphoma-2 protein (dilution, 1:500; Bcl-2; sc-783), cyclin D1 (dilution, 1:500; sc-717), p53 (dilution, 1:500; sc-6243), vascular endothelial growth factor (dilution, 1:500; VEGF; sc-13083) and $\beta$-actin (dilution, 1:500; sc-7210; all Santa Cruz Biotechnology, Inc., Dallas, TX, USA) for $1 \mathrm{~h}$ at room temperature. The membrane was washed with TBST and incubated with secondary antibody mouse anti-rabbit IgG-HRP (sc-2357, dilution, 1:3,000; Santa Cruz Biotechnology, Inc.) at $37^{\circ} \mathrm{C}$ for $1 \mathrm{~h}$, and then assessed by an BeyoECL Plus (P0018; Beyotime Institute of Biotechnology). The optical density was analyzed using Quantity One software (version 3.0; Bio-Rad Laboratories, Inc.).

Statistical analysis. Data are expressed as the mean \pm standard error by SPSS software (version 20; SPSS, Inc., Chicago, IL, USA). Comparisons were made using ANOVA followed by Tukey's post hoc test for multiple comparisons. $\mathrm{P}<0.05$ was considered to indicate a statistically significant difference.

\section{Results}

Liriodenine suppresses MCF-7 cell viability. The chemical structure of liriodenine is presented in Fig. 1. In order to investigate the effects of liriodenine on human breast cancer MCF-7 cells, an MTT assay was performed to analyze the cellular viability. Following a 24, 48 or 72 h treatment, liriodenine induced a dose-dependent decrease in the cellular viability of the MCF-7 cells. Particularly, following a 48- or 72-h treatment, liriodenine (1 or $10 \mu \mathrm{M})$ significantly decreased the cellular viability of the MCF-7 cells (Fig. 2).

Liriodenine induces apoptosis of MCF-7 cells. In order to detect whether liriodenine affects the apoptotic rate of MCF-7 cells, flow cytometry was performed on the cells. As shown in Fig. 3, following a 48-h treatment, $10 \mu \mathrm{M}$ liriodenine significantly increased the apoptotic rate of the MCF-7 cells compared with the control group ( $0 \mu \mathrm{M}$ liriodenine $)$.

Liriodenine induces apoptotic nucleoli in MCF-7 cells. In the present study, apoptotic nucleoli of the MCF-7 cells, as induced by liriodenine, were observed. DAPI was used to stain 


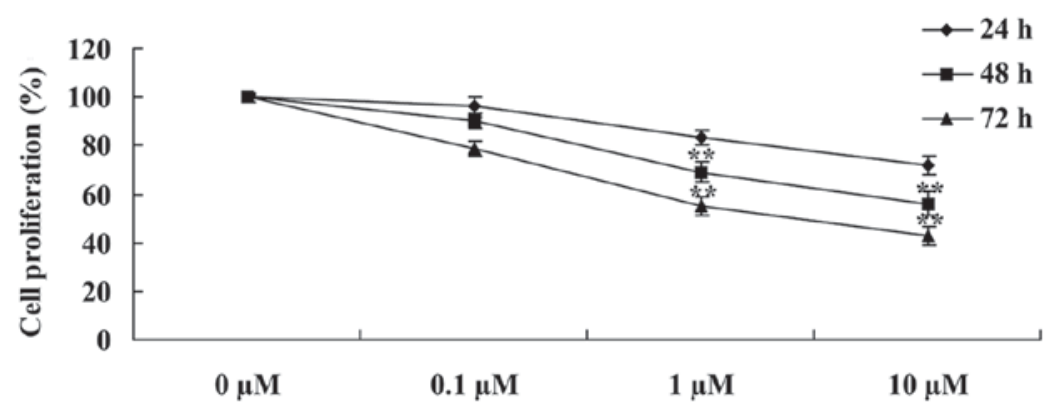

Figure 2. Liriodenine suppresses the cell proliferation of MCF-7 cells. ${ }^{* *} \mathrm{P}<0.01$ compared with the control group $(0 \mu \mathrm{M}$ liriodenine).

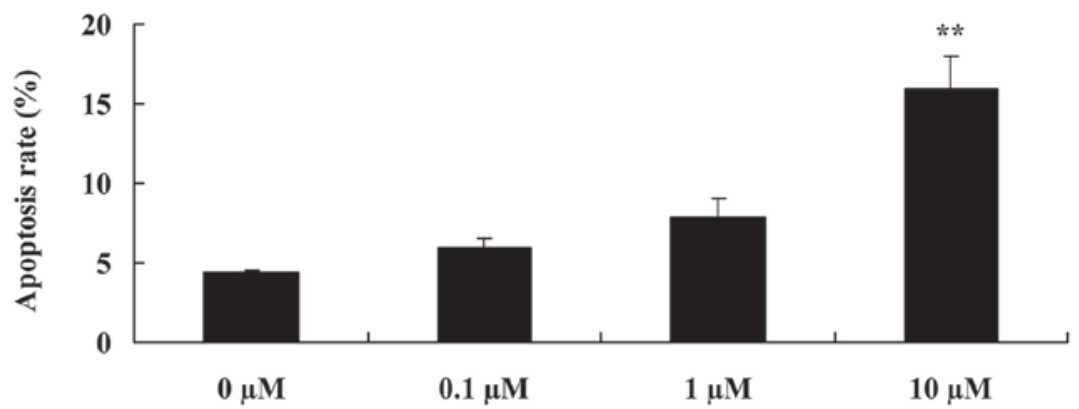

Figure 3. Liriodenine induces the apoptosis of MCF-7 cells. ${ }^{* *} \mathrm{P}<0.01$ compared with the control group ( $0 \mu \mathrm{M}$ liriodenine).

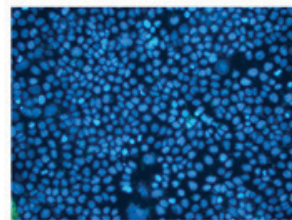

$0 \mu \mathrm{M}$

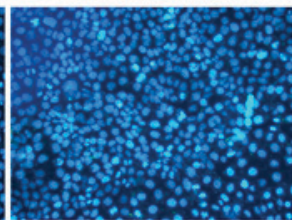

$0.1 \mu \mathrm{M}$

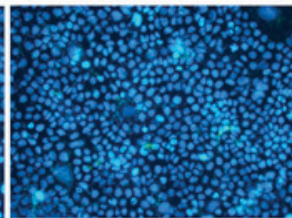

$1 \mu \mathrm{M}$

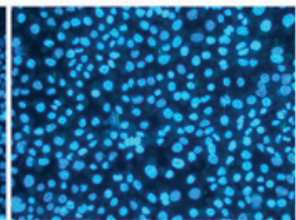

$10 \mu \mathrm{M}$

Figure 4. Liriodenine induces apoptotic nucleoli in MCF-7 cells. ${ }^{* *} \mathrm{P}<0.01$ compared with the control group $(0 \mu \mathrm{M}$ liriodenine $)$.

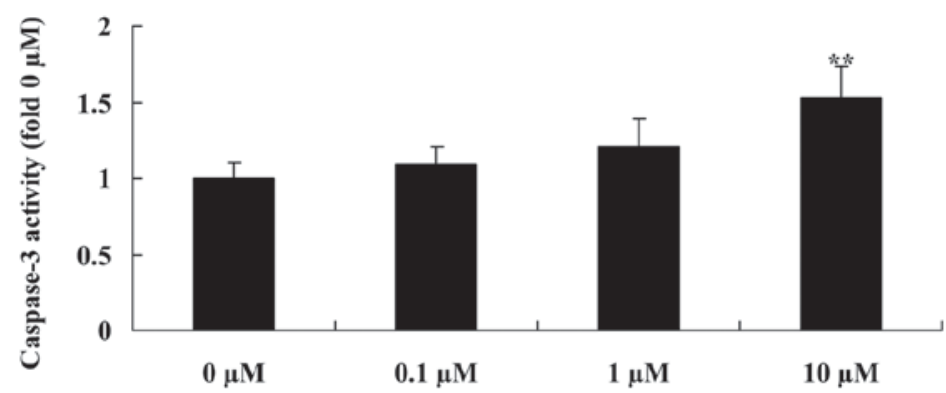

Figure 5. Liriodenine activates the caspase-3 activity of MCF-7 cells. ${ }^{* *} \mathrm{P}<0.01$ compared with the control group ( $0 \mu \mathrm{M}$ liriodenine).

the apoptotic nucleoli of the MCF-7 cells. A concentration of $10 \mu \mathrm{M}$ liriodenine significantly increased the formation of the apoptotic nucleoli of the MCF-7 cells compared with the control group (0 $\mu \mathrm{M}$ liriodenine) (Fig. 4).

Liriodenine activates caspase-3 activity of MCF-7 cells In order to detect whether liriodenine affects thecaspase-3 activity of MCF-7 cells, a Caspase 3 Activity Assay Kit was used to analyse the caspase- 3 activity of MCF-7 cells treated with liriodenine. A concentration of $10 \mu \mathrm{M}$ liriodenine significantly increased the caspase- 3 activity of the MCF-7 cells following a 48-h treatment compared with the control group (0 $\mu \mathrm{M}$ liriodenine) (Fig. 5).

Liriodenine inhibits Bcl-2 protein expression in MCF-7 cells. The present study investigated the mechanism of liriodenine on MCF-7 cells. Bcl-2 protein is an important protein for apoptosis. Bcl-2 protein expression was significantly suppressed by $10 \mu \mathrm{M}$ liriodenine in MCF-7 cells following a 48-h treatment compared with the control group (0 $\mu \mathrm{M}$ liriodenine) (Fig. 6). 
A

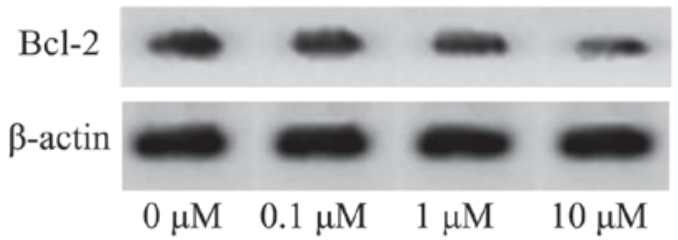

B

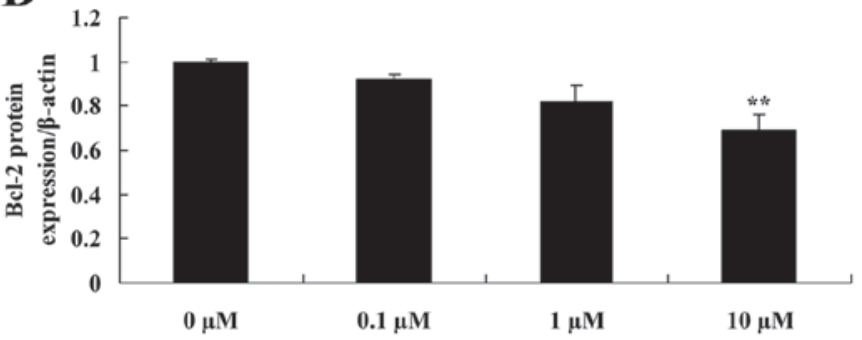

Figure 6. Liriodenine inhibits the Bcl-2 protein expression of MCF-7 cells. (A) The effect of liriodenineon Bcl-2 protein expression was investigated by western blot analysis. (B) Statistical analysis of Bcl-2 protein expression in MCF-7 cells. ${ }^{* *} \mathrm{P}<0.01$ compared with the control group $(0 \mu \mathrm{M}$ liriodenine). Bcl-2, B-cell lymphoma-2.

A

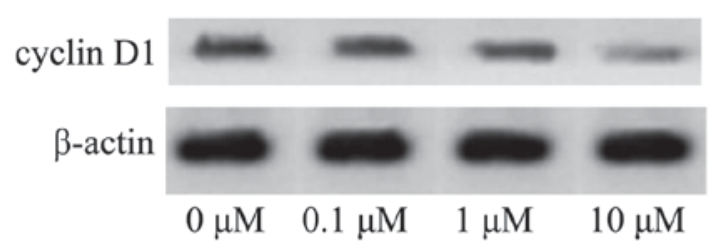

B

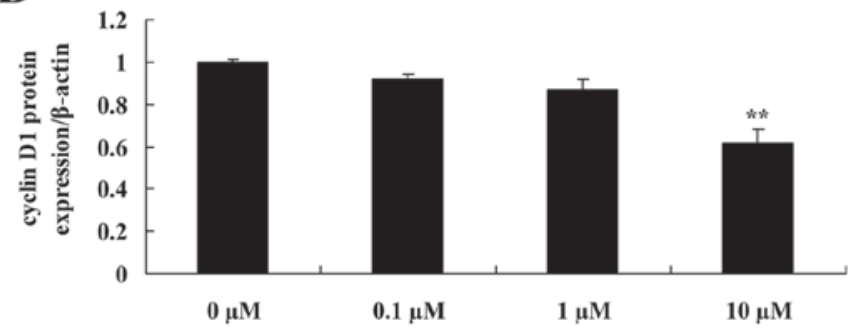

Figure 7. Liriodenine inhibits the cyclin D1 protein expression of MCF-7 cells. (A) The effect of liriodenineon cyclin D1 protein expression was investigated by western blot analysis. (B) Statistical analysis of cyclin D1 protein expression in MCF-7 cells. ${ }^{* * *} \mathrm{P}<0.01$ compared with the control group $(0 \mu \mathrm{M}$ liriodenine).

A

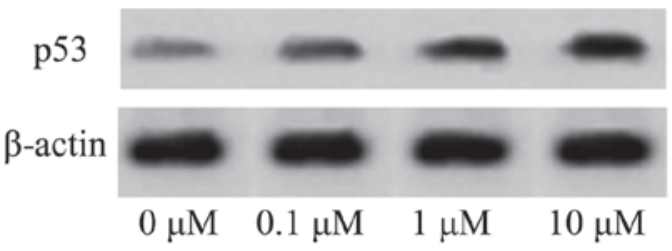

B

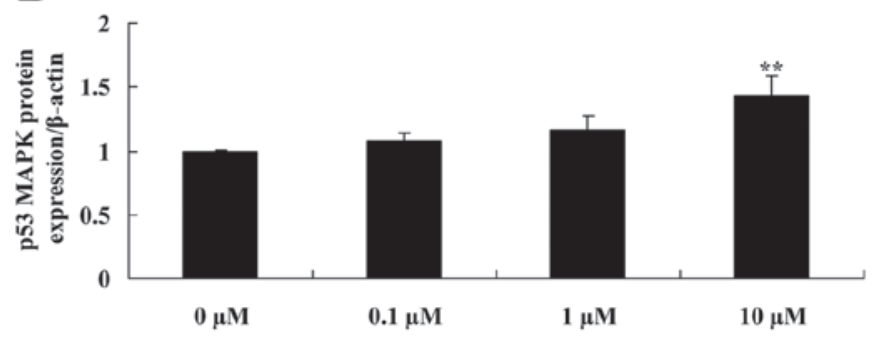

Figure 8. Liriodenine promotes the p53 protein expression of MCF-7 cells. (A) The effect of liriodenineon p53 protein expression was investigated by western blot analysis. (B) Statistical analysis of $\mathrm{p} 53$ protein expression in $\mathrm{MCF}-7$ cells. ${ }^{* *} \mathrm{P}<0.01$ compared with the control group $(0 \mu \mathrm{M}$ liriodenine $)$.

A

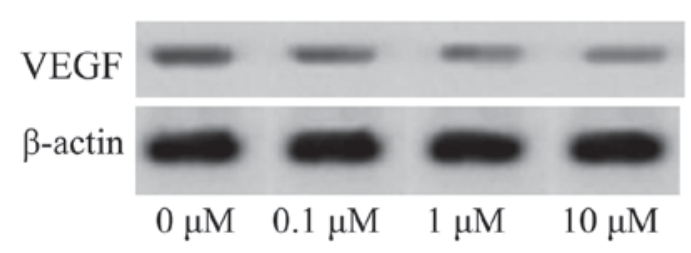

B

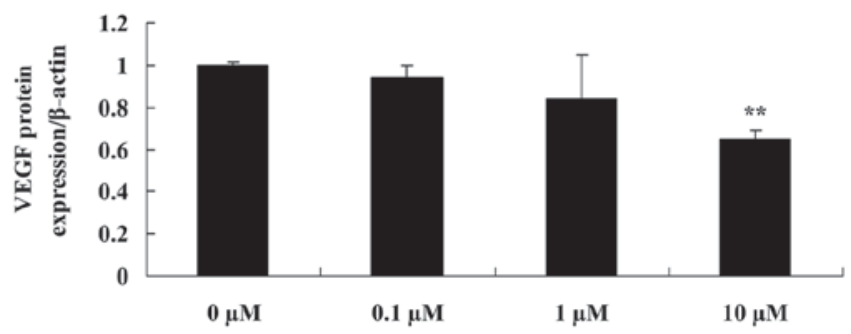

Figure 9. Liriodenine supresses the VEGF protein expression of MCF-7 cells. (A) The effect of liriodenineon VEGF protein expression was investigated by western blot analysis. (B) Statistical analysis of VEGF protein expression in MCF-7 cells. ${ }^{* *} \mathrm{P}<0.01$ compared with the control group ( $0 \mu \mathrm{M}$ liriodenine). VEGF, vascular endothelial growth factor.

Liriodenine inhibits cyclin D1 protein expression in MCF-7 cells. In order to investigate the possible effects of liriodenine on apoptosis of MCF-7 cells, cyclin D1 protein expression was measured using western blot analysis. As shown in Fig. 7, cyclin D1 protein expression in the MCF-7 cells was significantly inhibited by $10 \mu \mathrm{M}$ liriodenine following a 48-h treatment compared with the control group $(0 \mu \mathrm{M}$ liriodenine). 
Liriodenine promotes p53 protein expression in MCF-7 cells. To investigate the effect of liriodenine on p53 protein expression in MCF-7 cells, western blot analysis was performed. As shown in Fig. 8, $10 \mu \mathrm{M}$ liriodenine significantly activated the 553 protein expression of MCF-7 cells compared with the control group (0 $\mu \mathrm{M}$ liriodenine).

Liriodenine promotes VEGF protein expression in $M C F-7$ cells. To investigate the effects of liriodenine on the VEGF protein expression of MCF-7 cells, VEGF protein expression was measured using western blot analysis. As shown in Fig. 9, VEGF protein expression in MCF-7 cells was significantly suppressed by $10 \mu \mathrm{M}$ liriodenine compared with the control group (0 $\mu \mathrm{M}$ liriodenine).

\section{Discussion}

Breast cancer is a common malignant cancer that greatly threatens the health of women. During the occurrence and progression of breast cancer, there are numerous factors affecting the biological behavior of tumor cells (5). The development, metastasis and prognosis of breast cancer are associated with the mutation and abnormal expression of oncogenes (17). As tumor suppressor genes are often mutated in cancer cells, p53 may be divided into wild-type and mutant-type. Studies have demonstrated that the genetic mutation of p53 is associated with the resistance of breast cancer $(8,18)$. The present study demonstrated that liriodenine significantly decreased cellular viability, induced the apoptotic rate, increased the formation of apoptotic nucleoli and increased the caspase-3 activity of MCF-7 cells. Some study reported that liriodenine exerts anticancer effects on human lung cancer cells (19) and human ovarian cancer cells (13).

As a biological marker of breast cancer, increased expression of cyclin D1 predicts a poor prognosis (20). Clinical studies have revealed that in tissues positive for cyclin D1, it has increased expression in aging cells, indicating that cyclin D1 may promote the cell cycle by increasing the speed of the G1 stage (21). Overexpression and amplification of cyclin D1 has no association with tumor size, lymphatic metastasis or amplification (22). With the exception of cyclin D1, the development of breast cancer may be associated with synergistic effects between other oncogenes and cancer suppressor genes, including $\mathrm{Rb}, \mathrm{Bcl}-2$ and ER (23). In the present study, it was revealed that liriodenine significantly suppressed Bcl-2 and cyclin D1 protein expression in MCF-7 cells. Nordin et al indicated that liriodenine inhibits proliferation of human ovarian cancer cells through suppression of Bcl-2 and cytochrome $c$ (13). Therefore, the effect of liriodenine on MCF-7 cells may be associated with Bcl-2 and cyclin D1 expression.

The classical cytological function of p53 is as a transcription factor that has low expression under physiological status of non-stimulus, and may respond to various physiological stimulation pathology stimuli in order to be activated (24). Through regulating these processes, injured cells may be repaired and the apoptosis of badly damaged cells may be promoted. Thus, cell carcinogenesis triggered by the accumulation of DNA injury may be avoided. p53 may perform a braking function in vicious transformation, subsequently blocking injured cells from entering into the cell cycle and promoting the apoptosis of injured cells (25). It has also been identified that liriodenine significantly activates p53 protein expression in MCF-7 cells. Hsieh et al reported that liriodenine inhibited cell proliferation and mediated the activation of p53 expression in human hepatoma cells (12). The duration of the effect of liriodenine on MCF-7 cells may also contribute to p53 protein expression in in vitro experiments.

Studies on breast cancer have proposed that follicle-stimulating hormone may facilitate the expression of hypoxia-inducible factor- $\alpha$ and promotes the synthesis of VEGF $(26,27)$. VEGF can significantly facilitate the proliferation, invasion, migration and lumen formation in cancer cell (26). The present study identified that $10 \mu \mathrm{M}$ liriodenine significantly suppressed the VEGF protein expression of MCF-7 cells. Li et al proposed that liriodenine induces apoptosis through the down regulation of VEGF expression in human laryngo carcinoma cells (16). Therefore, VEGF expression may perform a crucial role in the liriodenine-induced apoptosis of MCF-7 cells.

In conclusion, the present study demonstrated that liriodenine significantly decreased cellular viability, induced the apoptotic rate, increased the formation of apoptotic nucleoli and increased the caspase-3 activity of MCF-7 cells. The potential mechanism underlying the antitumor effects of liriodenine may result from inhibition of Bcl-2, cyclin D1 and VEGF expression, and up regulation of p53 expression, which ultimately induces cellular apoptosis. Therefore, the present study indicated that liriodenine may be a potential novel drug for the treatment of breast cancer.

\section{Acknowledgements}

The present study was supported by the National Natural Science Foundation of China (grant no. 81260389) and the Science and Technology Support Program of Jiangxi Province (grant no. 1228).

\section{References}

1. Metzger-Filho O, de Azambuja E, Bradbury I, Saini KS, Bines J, Simon SD, Dooren VV, Aktan G, Pritchard KI, Wolff AC, et al: Analysis of regional timelines to set up a global phase III clinical trial in breast cancer: The adjuvant lapatinib and/or trastuzumab treatment optimization experience. Oncologist 18: 134-140, 2013.

2. Bower JE, Greendale G, Crosswell AD, Garet D, Sternlieb B, Ganz PA, Irwin MR, Olmstead R, Arevalo J and Cole SW: Yoga reducesinflammatory signalinginfatigued breastcancersurvivors: A randomized controlled trial. Psychoneuroendocrinology 43: 20-29, 2014.

3. Buckley A, McQuaid S, Johnson P and Buggy DJ: Effect of anaesthetic technique on the natural killer cell anti-tumour activity of serum from women undergoing breast cancer surgery: A pilot study. Br J Anaesth 113 (Suppl 1): i56-i62, 2014.

4. Ansari M, Porouhan P, Mohammadianpanah M, Omidvari S, Mosalaei A, Ahmadloo N, Nasrollahi H and Hamedi SH: Efficacy of ginger in control of chemotherapy induced nausea and vomiting in breast cancer patients receiving doxorubicin-based chemotherapy. Asian Pac J Cancer Prev 17: 3877-3880, 2016.

5. Mrózek E, Layman R, Ramaswamy B, Lustberg M, Vecchione A, Knopp MV and Shapiro CL: Phase II trial of neoadjuvant weekly nanoparticle albumin-bound paclitaxel, carboplatin, and biweekly bevacizumab therapy in women with clinical stage II or III HER2-negative breast cancer. Clin Breast Cancer 14: 228-234, 2014.

6. Pu Z, Zhang X, Chen Q, Yuan X and Xie H: Establishment of an expression platform of OATP1B1 388GG and 521CC genetic polymorphism and the therapeutic effect of tamoxifen in MCF-7 cells. Oncol Rep 33: 2420-2428, 2015. 
7. Hu D, Su C, Jiang M, Shen Y, Shi A, Zhao F, Chen R, Shen Z, Bao J and Tang W: Fenofibrate inhibited pancreatic cancer cells proliferation via activation of p53 mediated by upregulation of LncRNA MEG3. Biochem Biophys Res Commun 471: 290-295, 2016.

8. Shokouh TZ, Ezatollah A and Barand P: Interrelationships Between Ki67, HER2/neu, p53, ER, and PR status and their associations with tumor grade and lymph node involvement in breast carcinoma subtypes: Retrospective-observational analytical study. Medicine (Baltimore) 94: e1359, 2015.

9. Antony ML, Kim SH and Singh SV: Critical role of p53 upregulated modulator of apoptosis in benzyl isothiocyanate-induced apoptotic cell death. PLoS One 7: e32267, 2012.

10. Wong FC, Woo CC, Hsu A and Tan BK: The anti-cancer activities of Vernonia amygdalina extract in human breast cancer cell lines are mediated through caspase-dependent and p53-independent pathways. PLoS One 8: e78021, 2013.

11. Ali A, Shah AS and Ahmad A: Gain-of-function of mutant p53. Mutant p53 enhances cancer progression by inhibiting KLF17 expression in invasive breast carcinoma cells. Cancer Lett 354 87-96, 2014.

12. Hsieh TJ, Liu TZ, Chern CL, Tsao DA, Lu FJ, Syu YH, Hsieh PY, $\mathrm{Hu}$ HS, Chang TT and Chen CH: Liriodenine inhibits the proliferation of human hepatoma cell lines by blocking cell cycle progression and nitric oxide-mediated activation of p53 expression. Food Chem Toxicol 43: 1117-1126, 2005.

13. Nordin N, Majid NA, Hashim NM, Rahman MA, Hassan Z and Ali HM: Liriodenine, an aporphine alkaloid from Enicosanthellum pulchrum, inhibits proliferation of human ovarian cancer cells through induction of apoptosis via the mitochondrial signaling pathway and blocking cell cycle progression. Drug Des Devel Ther 9: 1437-1448, 2015.

14. Hufford CD, Sharma AS and Oguntimein BO: Antibacterial and antifungal activity of liriodenine and related oxoaporphine alkaloids. J Pharm Sci 69: 1180-1183, 1980.

15. De la Cruz-Chacón I, González-Esquinca AR, Guevara Fefer P and Jimenez Garcia LF: Liriodenine, early antimicrobial defence in Annona diversifolia. Z Naturforsch C 66: 377-384, 2011.

16. Li L, Xu Y and Wang B: Liriodenine induces the apoptosis of human laryngocarcinoma cells via the upregulation of p53 expression. Oncol Lett 9: 1121-1127, 2015.

17. Zuo S, Liu C, Wang J, Wang F, Xu W, Cui S, Yuan L, Chen X, Fan W, Cui M and Song G: IGFBP-rP1 induces p21 expression through a p53-independent pathway, leading to cellular senescence of MCF-7 breast cancer cells. J Cancer Res Clin Oncol 138 $1045-1055,2012$.
18. Verma S and Rao BJ: p53 suppresses BRCA2-stimulated ATPase and strand exchange functions of human RAD51. J Biochem 154: 237-248, 2013.

19. Chang HC, Chang FR, Wu YC and Lai YH: Anti-cancer effect of liriodenine on human lung cancer cells. Kaohsiung J Med Sci 20: 365-371, 2004.

20. Saxena NK, Vertino PM, Anania FA and Sharma D: Leptin-induced growth stimulation of breast cancer cells involves recruitment of histone acetyltransferases and mediator complex to CYCLIN D1 promoter via activation of Stat3. J Biol Chem 282: 13316-13325, 2007.

21. Feldt M, Bjarnadottir O, Kimbung S, Jirström K, Bendahl PO, Veerla S, Grabau D, Hedenfalk I and Borgquist S: Statin-induced anti-proliferative effects via cyclin D1 and p27 in a window-of-opportunity breast cancer trial. J Transl Med 13: 133, 2015.

22. Mohammadizadeh F, Hani M, Ranaee M and Bagheri M: Role of cyclin D1 in breast carcinoma. J Res Med Sci 18: 1021-1025, 2013.

23. Gonzalez-Sarrias A, Ma H, Edmonds ME and Seeram NP: Maple polyphenols, ginnalins A-C, induce S- and G2/M-cell cycle arrest in colon and breast cancer cells mediated by decreasing cyclins A and D1 levels. Food Chem 136: 636-642, 2013.

24. Coates AS, Millar EK, O'Toole SA, Molloy TJ, Viale G, Goldhirsch A, Regan MM, Gelber RD, Sun Z, Castiglione-Gertsch M, et al: Prognostic interaction between expression of p53 and estrogen receptor in patients with node-negative breast cancer: Results from IBCSG Trials VIII and IX. Breast Cancer Res 14: R143, 2012.

25. Zhang Z, Wang CZ, Du GJ, Qi LW, Calway T, He TC, Du W and Yuan CS: Genistein induces G2/M cell cycle arrest and apoptosis via ATM/p53-dependent pathway in human colon cancer cells. Int J Oncol 43: 289-296, 2013.

26. Liu S and Qian W: Need for clarification of data in a recent meta-analysis on vascular endothelial growth factor (VEGF) and risk of breast cancer. Cytokine 60: 596, 2012.

27. Groves MD, Hess KR, Puduvalli VK, Colman H, Conrad CA, Gilbert MR, Weinberg J, Cristofanilli M, Yung WK and Liu TJ: Biomarkers of disease: Cerebrospinal fluid vascular endothelial growth factor (VEGF) and stromal cell derived factor (SDF)-1 levels in patients with neoplastic meningitis (NM) due to breast cancer, lung cancer and melanoma. J Neurooncol 94: 229-234, 2009 